\title{
Involvement of Bim in Photofrin-Mediated Photodynamically Induced Apoptosis
}

\author{
Xianwang Wang ${ }^{a}$ Xiaobing He ${ }^{a}$ Shujuan $\mathrm{Hu}^{\mathrm{b}}$ Anbang Sun ${ }^{\mathrm{a}}$ Chengbiao $\mathrm{Lu}^{\mathrm{a}}$ \\ aLaboratory of Neuronal Network and Brain Diseases Modulation, School of Medicine, Yangtze \\ University, 'Institute of Physical Education, Yangtze University, Jingzhou, China
}

\section{Key Words}

Bim • Photofrin • Photodynamic therapy • Apoptosis

\begin{abstract}
Background/Aims: Photodynamic therapy (PDT) is a promising noninvasive technique, which has been successfully applied to the treatment of human cancers. Studies have shown that the $\mathrm{Bcl}-2$ family proteins play important roles in PDT-induced apoptosis. However, whether $\mathrm{Bcl}$-2-interacting mediator of cell death $(\mathrm{Bim})$ is involved in photodynamic treatment remains unknown. In this study, we attempt to determine the effect of Bim on Photofrin photodynamic treatment (PPT)-induced apoptosis in human lung adenocarcinoma ASTC-a-1 cells. Methods: The translocation of Bim/Bax of the cells were monitored by laser confocal scanning microscope. The levels of Bim protein and activated caspase-3 in cells were detected by western blot assay. Caspase-3 activities were measured by Caspase-3 Fluorogenic Substrate (Ac-DEVD-AFC) analysis. The induction of apoptosis was detected by Hoechst 33258 and PI staining as well as flow cytometry analysis. The effect of Bim on PPT-induced apoptosis was determined by RNAi. Results: BimL translocated to mitochondria in response to PPT, similar to the downstream pro-apoptotic protein Bax activation. PPT increased the level of Bim and activated caspase-3 in cells and that knockdown of Bim by RNAi significantly protected against caspase- 3 activity. PPT-induced apoptosis were suppressed in cells transfected with shRNA-Bim. Conclusion: We demonstrated the involvement of Bim in PPT-induced apoptosis in human ASTC-a-1 lung adenocarcinoma cells and suggested that enhancing Bim activity might be a potential strategy for treating human cancers.
\end{abstract}

Copyright $(2014$ S. Karger AG, Basel

\section{Introduction}

Photodynamic therapy (PDT), an efficient and promising treatment modality, which has been used and improved over the past two decades, is an oxidative stress that induces apoptosis in many human cancers in vitro and in vivo [1,2]. The apoptosis is an early response

Dr. Xianwang Wang

and Chengbiao Lu
Laboratory of Neuronal Network and Brain Diseases Modulation, School of Medicine, Yangtze University, Jingzhou 434023 (China)

Tel.+86-716-8062633, E-Mail 275379987@qq.com, E-Mail johnlu9001@hotmail.com 
of PDT, both during in vitro tumor cell killing and in vivo situations during tumor ablation [3-5]. Studies have shown that PDT-induced apoptosis relies on exposure of tumor cells to a photosensitizing drug followed by irradiation with visible light of appropriate wavelength, which activates tumor cell-associated photosensitizer to produce reactive oxygen species (ROS) [6-8]. Photofrin is a popular photosensitizer in PDT. Studies have shown that tumor cells apoptosis induced by Photofrin-PDT is mainly through mitochondrial damage and caspase- 3 activation $[8,9]$.

Bcl-2 family proteins play important roles in apoptosis, especially in mitochondrial death pathway. Stimuli such as ultraviolet (UV) radiation cause activation of c-Jun N-terminal kinase (JNK), resulting in phosphorylation and expression of Bcl-2 interacting mediator of cell death (Bim), a BH3-only protein of Bcl-2 family, and the release of phosphorylated Bim from dynein motor complex [10-13]. The released Bim promotes Bax activation in an indirect manner [14-16]. The activated Bax localize to the outer mitochondrial membrane $(\mathrm{OMM})$ and form oligomers to cause the release of cytochrome c, second mitochondriaderived activator of caspase/diablo homolog (Smac/DIABLO) and apoptosis inducing factor (AIF) $[17,18]$.

Previous studies have shown that some Bcl-2 family proteins, including Bcl-2, Bax, are involved in PDT-induced apoptosis and regulate the mitochondrial permeability transition (MPT) [1]. However, whether Bim is required in PDT-induced cancer cells apoptosis is not clear. In this study, human lung adenocarcinoma ASTC-a-1 cells, exposed to Photofrin photodynamic treatment (PPT), were applied to elucidate the contribution of Bim in PPTinduced apoptosis. The results clearly suggest that Bim translocates to mitochondrial membrane in PPT and that knockdown of endogenous Bim inhibits PPT-induced caspase-3 activity and apoptosis. Our results suggest that Bim might act as a new target of PPT in human cancer.

\section{Material and Methods}

\section{Reagents, Plasmids and antibodies}

Dulbecco's modified Eagle's medium (DMEM) was purchased from GIBCO (Grand Island, NY). Lipofectamine $^{\mathrm{TM}} 2000$ Reagent was purchased from Invitrogen (Carlsbad, CA). DNA Extraction kits were purchased from Qiagen (Valencia, CA). Hoechst 33258 and Propidium Iodide (PI) were obtained from Sigma (St.Louis, MO, USA). Annexin V (FITC) apoptosis detection kit was obtained from Bender Medsystems (Austria). Ac-DEVD-AFC was purchased from Alexis (Switzerland). Photofrin was got from QLT Phototherapeutics (Vancouver, BC, Canada). The plasmid of GFP-BimL was generated in our previously studies $[14,15]$. To construct pEGFP-N1-BimL, BimL was generated by PCR using 5'-ACACGCTAGCTATGGCCAAGCAACCTTCTGA-3' and 5'- ACACGGATCCACATGCCTTCTCCATACCAGAC-3' oligouncleotide primers. The PCR product was cloned into pEGFP-N1 vector following digestion with NheI and BamHI. The oligonucleotide of shRNA-BimL(5'-GCAACCTTCTGATGTAAGTTCTTCAAGAGAGAACTTACAT CAGAAGGTTGCTT-3') was purchased from GenePharma (Shanghai, China) and proven to reduce effectively endogenous BimL protein [15]. The plasmid of DsRed-Mit was kindly presented by Prof. Gotoh [19]. It is a molecular fluorescence probe, can localize at mitochondria in living cells selectively. GFP-Bax was kindly presented by Prof Gilmore [20]. Antibodies of anti-Bim, anti-caspase-3 and anti-actin were purchased from Cell Signaling (Hitchin, UK).

\section{Cell culture and transfection}

The human lung adenocarcinoma cell line (ASTC-a-1) was obtained from the Department of Medicine, Jinan University (Guangzhou, China). The cells were cultured in DMEM supplemented with $10 \%$ fetal calf serum (FCS), 100 units $/ \mathrm{ml}$ penicillin and $100 \mu \mathrm{g} / \mathrm{ml}$ streptomycin, $5 \% \mathrm{CO}_{2}$ at $37^{\circ} \mathrm{C}$ in a humidified incubator. Transfection was performed with Lipofectamine ${ }^{\mathrm{TM}}$ reagent according to the manufacturer's protocol and the medium was replaced with fresh culture medium after 5 hours. For fluorescence studies, the cells were transferred in 35-mm dish 24-48 hours after transfection. 


\section{Cellular Physiology Cell Physiol Biochem 2015;35:1527-1536 \begin{tabular}{l|l|l} 
and $10.1159 / 000373968$ & & $\begin{array}{l}\text { D 2015 S. Karger AG, Basel } \\
\text { www.karger.com/cpb }\end{array}$ \\
\hline
\end{tabular} \\ Wang et al.: Bim is Involved in Photodynamically Induced Apoptosis}

\section{Photodynamic treatment}

For photodynamic treatment, the light source was a helium-neon (He-Ne)laser (HN-1000, $632.8 \mathrm{~nm}$ ). Cells $\left(1 \times 10^{4}\right.$ per well) growing in $35 \mathrm{~mm}$ Petri dishes were incubated with Photofrin in the dark for 20 hours in culture medium to ensure the mitochondrial localization of Photofrin. Different irradiation fluences $\left(1-15 \mathrm{~J} / \mathrm{cm}^{2}\right)$ and various Photofrin doses $(5-20 \mu \mathrm{g} / \mathrm{ml})$ have been assayed in previous study [9]. Here, to study PPT induced cell apoptosis, the dose $\left(10 \mathrm{~J} / \mathrm{cm}^{2}\right.$ irradiation; $10 \mu \mathrm{g} / \mathrm{ml}$ Photofrin; $20 \mathrm{~h}$ incubation) was used. Briefly, ASTC-a-1 cells were incubated with $10 \mu \mathrm{g} / \mathrm{ml}$ Photofrin at $37^{\circ} \mathrm{C}$ for 20 hours before exposed to red light with an intensity of $10 \mathrm{~mW} / \mathrm{cm}^{2}$ and a total light dose of $10 \mathrm{~J} / \mathrm{cm}^{2}$. For the control group, cells were incubated in the same medium without Photofrin and without light exposure. For low-power laser irradiation (LPLI) group, cells were incubated in the same medium without Photofrin and with light exposure $\left(10 \mathrm{~J} / \mathrm{cm}^{2}\right)$ alone. After irradiation, cells were rinsed with PBS and added culture medium before observed using laser confocal scanning microscopy (LSM) or other treatments.

Time-lapse confocal fluorescence microscopy

A laser confocal scanning microscope (LSM 510/ConfoCor 2) combination system (Zeiss, Jena, Germany) was equipped with a Plan-Neofluar 40×/1.3 NA Oil DIC objective. To observe the activation of Bim, ASTC-a-1 cells were co-transfected with GFP-BimL and DsRed-Mit plasmids before treated with PPT. DsRed-Mit is a mitochondrial molecular fluorescence probe in living cells. For time-lapse imaging, cells culture dishes were mounted onto the microscope stage maintained at $37^{\circ} \mathrm{C}$ equipped with a temperaturecontrolled chamber (Tempcontrol 37-2 digital, Zeiss, Jena, Germany). Temperature variations of culture liquid were less than $0.2^{\circ} \mathrm{C}$ throughout the experimental process. GFP-BimL/Bax fluorescence was excited at $488 \mathrm{~nm}$ with an argon ion laser and its fluorescence emission was recorded through a 500-530 nm IR band-pass filter. Images of DsRed-Mit fluorescence from the cells were obtained using a $543 \mathrm{~nm}$ excitation light from a He-Ne laser and a $560 \mathrm{~nm}$ long-pass filter.

\section{Western blotting assays}

Western blot assays were described previously $[15,16]$. After various treatments, ASTC-a-1 cells were collected by Trypsin-EDTA Solution and washed three times in ice-cold PBS. Cell pellets lysed with ice-cold lysis buffer (PBS, 0.5\% Triton X-100, 0.5mM PMSF and Complete Protease Inhibitor Cocktail from Roche) and treated with sonication (100 W, 5 s/time, intervels $10 \mathrm{~s}, 10$ times/sample). After centrifugation, cell lysates (about 30-50 mg protein extract was loaded on each lane) were resolved by 10-15\% SDS-PAGE gel $\left(10 \times 10 \mathrm{~cm}^{2}\right)$, and then transferred onto a PVDF membrane (Bio-Rad). The resulting membrane was blocked with $10 \%$ skim milk in room temperature for 30 minutes, washed three times by TBST $(3 \times 10 \mathrm{~min})$ before incubated with designated primary antibodies at $4{ }^{\circ} \mathrm{C}$ overnight. Bim and caspase- 3 primary antibodies were used at 1:1000 dilutions, and Actin antibody was used at 1:2000 dilutions (diluted by TBST). The specific signal was amplified by HRP-conjugated secondary antibodies, developed by ECL Western Blotting Substrate Kit (Graffinbio) and visualized under Bio-Rad Gel Doc XR System.

\section{Fluorescence activated cell sorting (FACS) analysis}

The apoptosis of cells were quantified by Annexin V and PI staining method [21]. After various treatments, cells were collected and washed with PBS, pelleted at 5, $000 \mathrm{~g}$ for $15 \mathrm{~s}$, and suspended in $1 \mathrm{ml}$ of ice-cold PBS. The cell suspension solution was centrifuged at 1, $000 \mathrm{rpm}, 4^{\circ} \mathrm{C}$ for $10 \mathrm{~min}$. Suspended cell pellets in $200 \mu \mathrm{l}$ binding buffer, and incubated with $5 \mu \mathrm{l}$ of Annexin V-FITC $(10 \mu \mathrm{g} / \mathrm{ml})$ and $10 \mu \mathrm{l} \mathrm{PI}(10 \mu \mathrm{g} /$ $\mathrm{ml}$ ) for 10 minutes at room temperature as recommended by the manufacturer. Then cells were subjected to fluorescenceactivated cell sorting (FACS) analysis using a flow cytometer (FACS. Arla BD, USA) with apoptotic cells being Annexin V-positive/PI-negative.

\section{Fluorometric assay for caspase-3 activity}

For the detection of caspase-3 activity, PBS washed cell pellets (derive from either the medium or the adherent cells) were resuspended in extract buffer [25 mM HEPES (pH7.4), 0.1\% TritonX-100, 10\% glycerol, $5 \mathrm{mM}$ DTT, $1 \mathrm{mM}$ phenylmethylsulfonyl fluoride, $10 \mathrm{mg} / \mathrm{ml}$ pepstatin, and $10 \mathrm{mg} / \mathrm{ml}$ Leupeptin] and vortexed vigorously. $20 \mu \mathrm{l}$ of extract (corresponding to $10 \%$ of the sample) were incubated with the caspase-3 fluorogenic substrates Ac-DEVD-AFC at $100 \mu \mathrm{M}$ final concentration at room temperature, and caspase- 3 activity was measured continuously by monitoring the release of fluorigenic AFC at $37^{\circ} \mathrm{C}$. The 
Fig. 1. Mitochondria translocation of GFP-BimL in ASTC-a-1 cells in response to PPT. (A) Cells were co-transfected with GFPBimL and DsRed-Mit expression plasmids before PPT (Photofrin $10 \mu \mathrm{g} / \mathrm{ml}+10 \mathrm{~J} / \mathrm{cm}^{2}$ irradiation). After PPT, images of fluorescence were recorded by LSM. GFP fluorescence of Bim was excited at $488 \mathrm{~nm}$ with an argon ion laser and its fluorescence emission was recorded through a 500-530 nm IR band-pass filter. DsRed fluorescence was excited at 543 $\mathrm{nm}$ with a helium-neon laser and its emitted light was recorded through a $560 \mathrm{~nm}$ long-pass filter. Bar, $10 \mu \mathrm{m}$. (B) The detail of the subcellular localization of BimL in response to PPT-induced apoptosis. Bar, $10 \mu \mathrm{m}$.

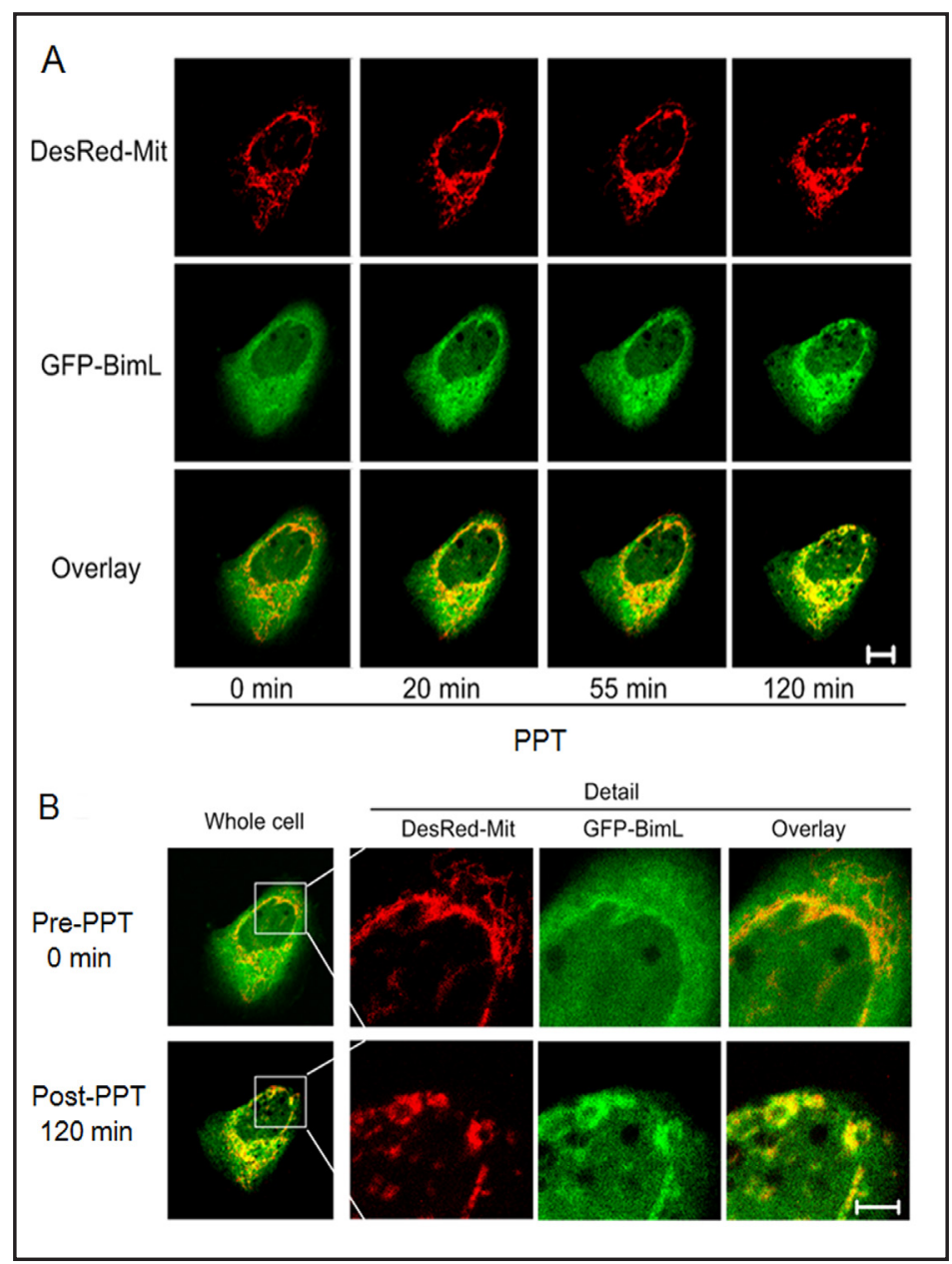

excitation wavelength of AFC was $400 \mathrm{~nm}$ and the emission wavelength was $530 \mathrm{~nm}$ using auto microplate reader (Infinite M200, Tecan, Austria). As a parallel study to confirm and compare the caspase-3 detection in our experiments, batch of cells were exposed to UV irradiation $[15,16]$, which a well-established protocol to induce apoptosis. For UV irradiation-induced apoptosis, culture medium was removed, and cells were rinsed with PBS and irradiated at fluence of $120 \mathrm{~mJ} / \mathrm{cm}^{2}\left(253.7 \mathrm{~nm}, 200 \mu \mathrm{W} / \mathrm{cm}^{2}\right)$, and then medium was restored.

\section{Statistical analysis}

All data represent at least three independent experiments and are expressed as the mean \pm SEM. Differences between groups were compared using Student's T tests by SPSS software, and significance was accepted at $P<0.05$.

\section{Results}

Mitochondria translocation of GFP-BimL in response to PPT

To monitor the mitochondria translocation of Bim in response to PPT, ASTC-a-1 cells were co-transfected with GFP-BimL and DsRed-Mit expression plasmids. Laser confocal scanning microscopy (LSM) images showed that BimL had a cytoplasmic distribution before PPT, while BimL translocated to mitochondria gradually and colocalized with mitochondria about 120 min after PPT (Fig. 1A). In order to demonstrate mitochondrial localization of Bim after PPT more clearly, part region of cell with higher magnification was presented in Fig. 1B. From these magnified images, it is confirmed that BimL reside in cytosol before PPT. Instead, BimL translocated to mitochondria after PPT.

\section{KARGER}




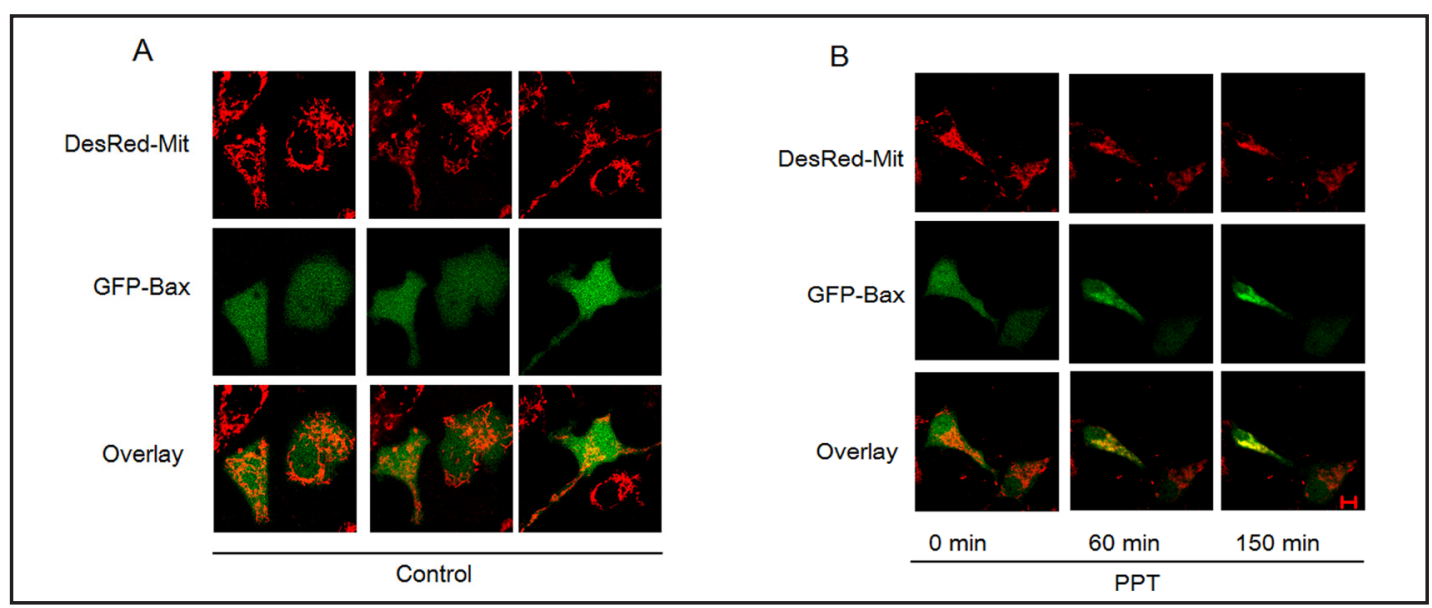

Fig. 2. Bax translocation to mitochondria in response to PPT. Cells were co-transfected with GFP-Bax and DsRed-Mit expression plasmids. (A) Images of fluorescence were recorded by LSM. GFP was excited at 488 $\mathrm{nm}$ with an argon ion laser and its fluorescence emission was recorded through a 500-530 nm IR band-pass filter. DsRed was excited at $543 \mathrm{~nm}$ with a helium-neon laser and its emitted light was recorded through a $560 \mathrm{~nm}$ long-pass filter. (B) Cells treated with PPT (Photofrin $10 \mu \mathrm{g} / \mathrm{ml}+10 \mathrm{~J} / \mathrm{cm}^{2}$ irradiation), images of GFP and DsRed fluorescence were recorded by LSM. Bar, $10 \mu \mathrm{m}$.

Mitochondria translocation of GFP-Bax in response to PPT

Similar above treatment, ASTC-a-1 cells were co-transfected with GFP-Bax and DsRedMit before PPT. The activation of Bax in control cells or PDT-induced apoptotic cells was observed. In control cells, Bax was distributed evenly in both cytoplasm and nucleus (Fig. 2A). However, Bax translocated to mitochondria and eventually formed clusters in mitochondria after PPT (Fig. 2B).

Knockdown of Bim by shRNA-Bim inhibited the activity of caspase-3 after PPT

Western blot assays were performed to test the expression levels of Bim and the effect of Bim activation on the activity of caspase-3 in response to PPT. As shown in Figure 3A, an increased expression level of Bim proteins was seen in the samples treated with PPT at 5 and $10 \mathrm{~J} / \mathrm{cm}^{2}$ light doses (lanes 3 and 4 ), but not in samples treated with Photofrin alone (Fig. 3A, lane 2). Statistical analysis further confirmed that PPT increased the levels of Bim (Fig. 3B). As shown in Figures 3C and 3D, the activated caspase-3 of PPT \& shRNA group is less than that of PPT alone group.

To further confirm above observation, AFC (an indicator of caspase-3 activation) release assay was applied. Activated caspase-3 but not pro-caspase- 3 does exert proteolytic activation on the Ac-DEVD-AFC substrate [21, 22]. As shown in Fig. 3E, after incubation with Ac-DEVD-AFC for 1 hour, significant increase of caspase-3 activity was observed at 4 hour after PPT (column 5) compared with control. There were no significant increases of caspase-3 activity in Photofrin and LPLI group (column 2 and 3). The cleavage of AcDEVD-AFC in response to caspase-3 activation was remarkably inhibited by shRNA-BimL transfection (column 6). These results demonstrated that Bim was involved in the PPTinduced caspase- 3 activity, which was consistent with the result by western blot analysis.

Knockdown of Bim by shRNA-Bim reduced PPT-mediated ASTC-a-1 cells apoptosis

The Hoechst 33258, a standard sensitive fluorochrome of DNA, was used to assess changes in nuclear morphology following PPT. As shown in Fig. 4A, the nuclei in control cells exhibited diffused staining of the chromatin. However, the cells in PPT group underwent typical apoptotic changes such as chromatin condensation, margination and shrunken nucleus.

We further determine the effect of Bim on PPT-induced cell apoptosis by flow cytometry. As shown in Fig. 4B, control cells displayed a low background of staining with either Annexin 
A

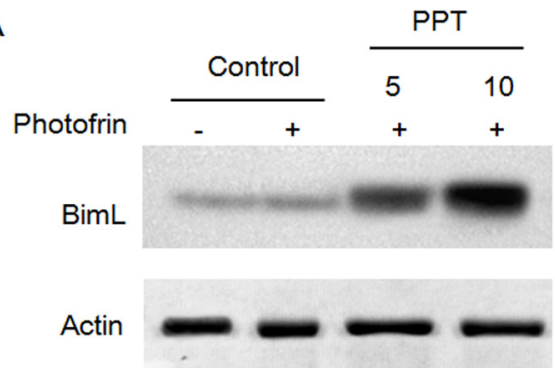

$\mathrm{B}$

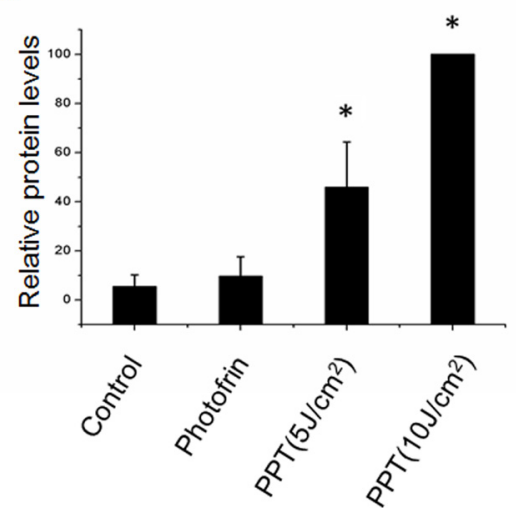

C Irradiation shRNA-BimL

Pro-caspase-3

Cleaved-caspase-3

BimL

Actin
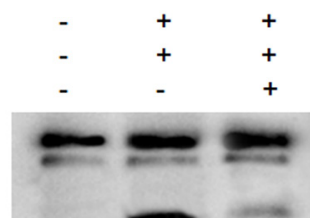

$\mathrm{D}$

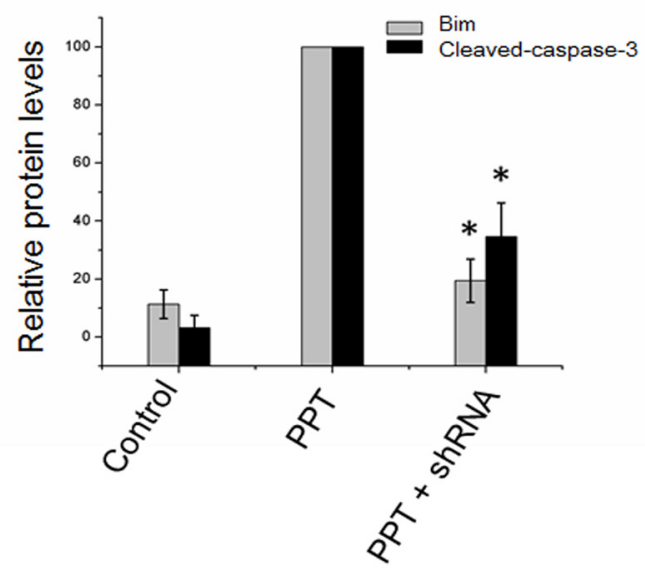

$\mathrm{E}$

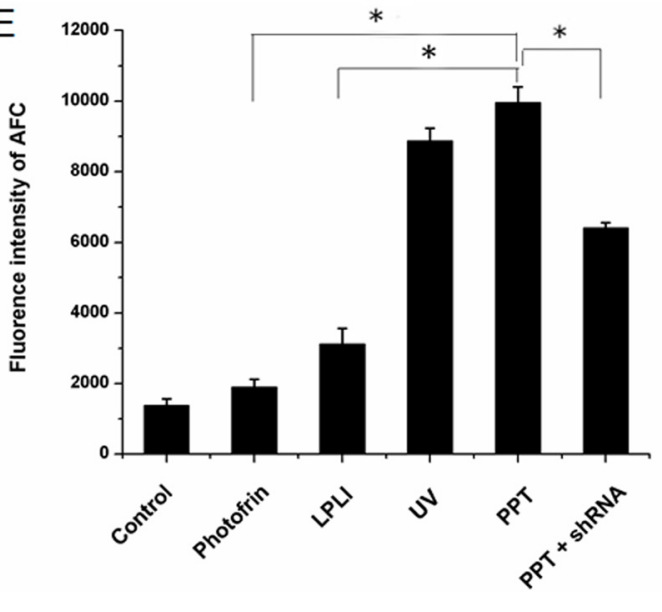

Fig. 3.The protein expression levels of Bim and caspase-3 in response to PPT. (A) ASTC-a-1 cells were randomly divided into four groups: Control group (lane 1), Photofrin group $(10 \mu \mathrm{g} / \mathrm{ml}$, without irradiation, lane 2), $5 \mathrm{~J} / \mathrm{cm}^{2}$ PPT group (Photofrin $10 \mu \mathrm{g} / \mathrm{ml}+5 \mathrm{~J} / \mathrm{cm}^{2}$ irradiation, lane 3) and $10 \mathrm{~J} / \mathrm{cm}^{2} \mathrm{PPT}$ group (Photofrin $10 \mu \mathrm{g} / \mathrm{ml}+10 \mathrm{~J} / \mathrm{cm}^{2}$ irradiation, lane 4). Western blot analysis was performed to detect the levels of Bim. Actin was used as a control. (B) Quantitative analysis of the relative levels of Bim in figure (A). Data represent mean \pm SEM of three independent experiments ( ${ }^{*} \mathrm{P}<0.05$ vs. control). (C) ASTC-a- 1 cells were randomly divided into three groups: Control group (lane 1), PPT group (Photofrin $10 \mu \mathrm{g} / \mathrm{ml}+10 \mathrm{~J} /$ $\mathrm{cm}^{2}$ irradiation, lane 2) and PPT \& shRNA group (Photofrin $10 \mu \mathrm{g} / \mathrm{ml}+10 \mathrm{~J} / \mathrm{cm}^{2}$ irradiation + shRNA-BimL, lane 3). Western blot analysis was performed to detect the levels of Bim and caspase-3, respectively. Actin was used as a control. (D) Quantitative analysis of the relative levels of Bim and activated aspase-3 in figure (C). Data represent mean \pm SEM of three independent experiments $\left({ }^{*} \mathrm{P}<0.05\right.$ vs. PPT group). (E) ASTC-a- 1 cells were randomly divided into six groups: Control group (column 1), Photofrin group (10 $\mu \mathrm{g} / \mathrm{ml}$, column 2), LPLI group (10 J/ $\mathrm{cm}^{2}$ light irradiation alone, column 3), UV irradiation group $\left(120 \mathrm{~mJ} / \mathrm{cm}^{2}\right.$, a parallel positive control, column 4), PPT group (Photofrin $10 \mu \mathrm{g} / \mathrm{ml}+10 \mathrm{~J} / \mathrm{cm}^{2}$ irradiation, column 5) and PPT \& shRNA group (Photofrin $10 \mu \mathrm{g} / \mathrm{ml}+10 \mathrm{~J} / \mathrm{cm}^{2}$ irradiation + shRNA-BimL, column 6 ). Caspase-3 activity was measured using the fluorescence substrate Ac-DEVD-AFC. Data shown in figure is mean $\pm \mathrm{SD}$ from at least three experiments. ${ }^{*} P<0.05$ vs. PPT group (column 5 ).

V (0.99 \%) or PI (0.65\%). In light irradiation alone group (LPLI), Annexin V- and PI-positive cells were $1.15 \%$ and $0.56 \%$, respectively. In PPT group, Annexin V- and PI-positive cells 
Fig. 4. Apoptosis induced by PPT in ASTC-a-1cells. (A) Four hours posttreated cells with PPT (Photofrin 10 $\mu \mathrm{g} / \mathrm{ml}+10 \mathrm{~J} / \mathrm{cm}^{2}$ irradiation), nuclear morphology was detected by Hoechst 33258 staining and examined by fluorescence microscope. Control cells with dispersive light blue nuclei and intact structure. With PPT treated, cell shrinkage, chromatin condensation and margination in the nucleus were visualized. (B) ASTC-a-1 cells were randomly divided into four groups: Control group, LPLI group (10 J/ $\mathrm{cm}^{2}$ light irradiation alone), PPT group (Photofrin $10 \mu \mathrm{g} / \mathrm{ml}+10 \mathrm{~J} / \mathrm{cm}^{2}$ irradiation) and PPT \& shRNA group (Photofrin $10 \mu \mathrm{g} /$ $\mathrm{ml}+10 \mathrm{~J} / \mathrm{cm}^{2}$ irradiation + shRNABimL). Then cells stained with $5 \mu \mathrm{l}$ of annexinV-FITC $(10 \mu \mathrm{g} / \mathrm{ml})$ and $10 \mu \mathrm{l}$ propidium iodide $(10 \mu \mathrm{g} / \mathrm{ml})$ for 10 min before being subjected to flow cytometry apoptosis analysis.
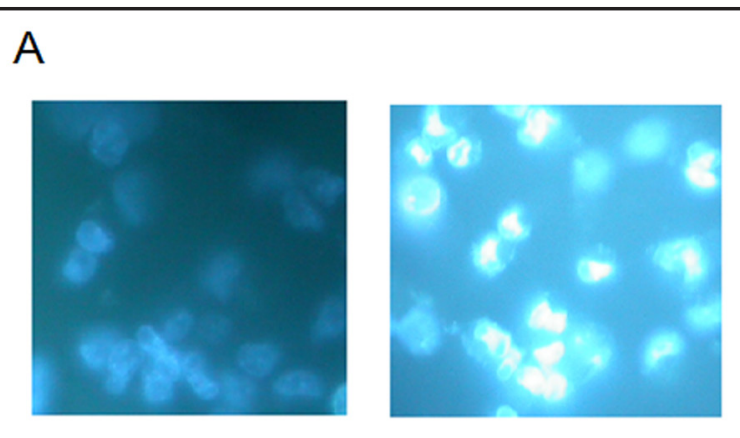

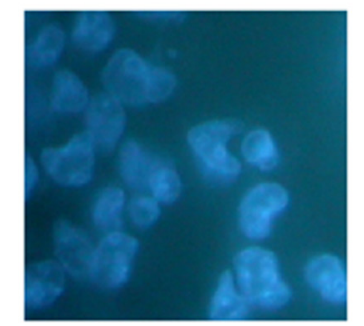

Control

$\mathrm{B}$

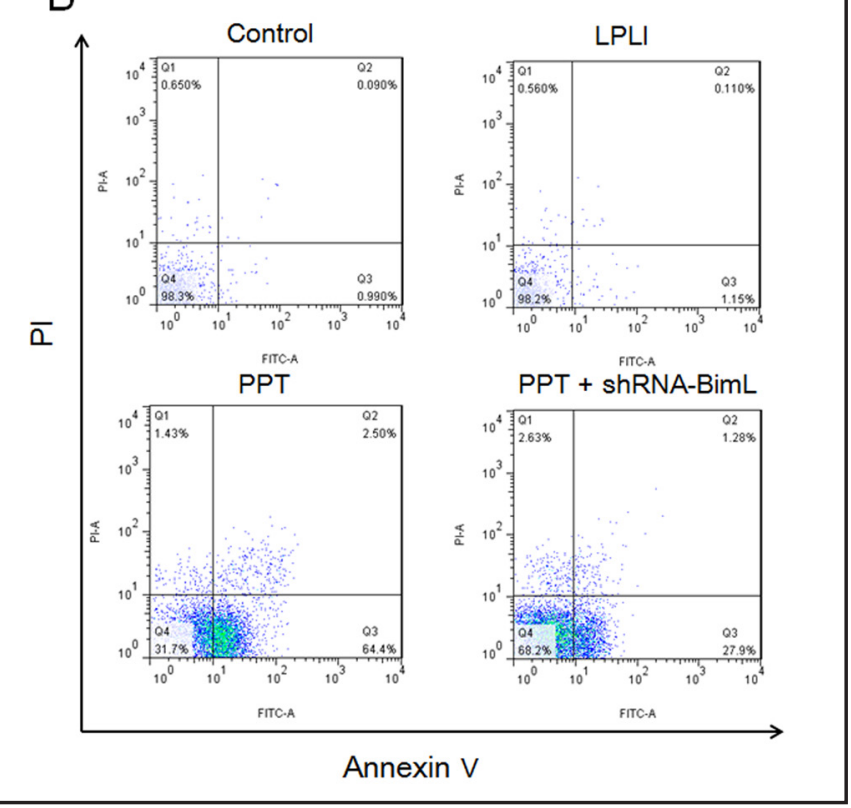

were dramatically increased to $64.4 \%$ and $1.43 \%$, respectively. However, Annexin V-positive cells were reduced to $27.9 \%$ after transfected with shRNA-BimL, suggesting that Bim was important in PPT-induced apoptosis.

\section{Discussion}

In the past few years, Bim has attracted increasing attention as a plausible target for tumor therapy. Bim is activated by several different manners in response to diverse cytotoxic signals. In current study, we showed that PPT-induced mitochondrial translocation of GFPBimL in ASTC-a-1 cells, which was similar to the previous results after UV irradiation 
treatment [14]. Studies indicate that Bim is phosphorylated by multiple kinases such as extracellular-regulated kinase (ERK), c-Jun N-terminal kinase (JNK), and protein kinase B (Akt), and their phosphorylation modifications affect the expression level or the pro-apoptotic function of Bim [23-25]. As an upstream factor of Bax, Bim is activated and dissociated from dynein motor complex to promote Bax activation on the outer mitochondrial membrane in an indirect manner [15], which further mediate mitochondrial apoptotic pathway. Transcription of Bim is regulated by FOXO3a, CHOP-C/EBP $\alpha$ or c-Jun in various cell lines $[16,23]$. Western blot assay has shown that PPT-induced in higher level expression of Bim protein in ASTC-a-1 cells and that knockdown of endogenous Bim by shRNA-BimL resulted in decreased levels of activated caspase- 3 and the reduced apoptotic rate. Both Bim protein expression levels and phosphorylated levels play important roles in the apoptotic pathway, suggesting that the upstream factors, such as FOXO and JNK, might be involved in the role of PPT. Proper control of Bim transcriptional and posttranslational levels provides selective therapeutic effects for some tumors.

The mitochondrial localization of Photofrin is essential for mitochondrial permeability transition (MPT) regulation and mitochondrial damage. ROS production is likely the origin of PPT-induced mitochondrial apoptotic pathway in ASTC-a-1 cells. The light irradiation triggers Photofrin photosensitization in mitochondria, affecting the activation of Bim, which promotes Bax activation and leads to caspase- 3 mediated apoptotic pathway. Study showed that the level of nitrosylhemoglobin, a stable complex of NO, increased in the course of PDT [26], suggesting that NO is a potential mediator in the ROS-induced cell death process. Imbalance of $\mathrm{Ca}^{2+}$ homeostasis might also correlate with the effects of PDT [27]. Moreover, protoporphyrin IX (PpIX) has been reported to inhibit tumor cell proliferation by induction of DNA damage and cell cycle arrest [28].

Recently, some promising strategies were developed to get the high efficient of PDT. To enhance localization of Photofrin to tumors, the tumor-localizing graft copolymer poly (ethylene glycol)-grafted poly (l-lysine) have been developed, which interact with Photofrin through ionic and hydrophobic interactions [29]. Electric field-assisted delivery of photofrin, electroporation, to the breast adenocarcinoma cells (MCF-7) and normal Chinese hamster ovary cells ( $\mathrm{CHO}$ ) has been found to enhance cellular uptake of Photofrin, which reduces effective dose and exposure time diminishing side effects of the therapy [30]. The efficacy of PDT is also affected by combining with some other drugs, such as Celecoxib, Dihydroartemisinin (DHA), and microRNAs (miRs), which regulate either the signaling pathway or gene expression in some cancer cell lines [31-33]. For example, overexpression of miR-130a could theoretically lead to more efficient PDT in resistant cell lines affecting adaptation to ROS stress, such as decreasing the expression of Sirtuin protein family, which regulates FOXO3a/Bim pathway and participates in a lot of neurodegenerative disorders [33-35]. An upconversion nanoparticle-Zinc phthalocyanine based nanophotosensitizer for PDT has been proven to result in the high ${ }^{1} \mathrm{O}_{2}$ production, leading to a secure and efficient PDT treatment [36].

To establish an efficient model for this therapy, more efforts are needed. Although we have identified Bim involvement on PPT-induced caspase- 3 activty and apoptosis, further experimentation will be needed to determine the molecular mechanism of Bim in PDT. Different photosensitizers may act along different routes and exert different effects on the cells [4].

In summary, we have identified for the first time that Bim is involved in PPT-induced apoptosis. The result suggests that Bim act as a potential target protein for PDT in human cancer therapy.

\section{Abbreviation}

GFP and DsRed (green and red fluorescent protein); PDT (photodynamic therapy); Bim (Bcl-2-interacting mediator of cell death); FoxO3a (fork-head boxO3a); shRNA (short 


\begin{tabular}{|c|c|c|}
\hline Cellular Physiology & Cell Physiol Biochem 2015;35:1527-1536 & \\
\hline and Biochemistry & \begin{tabular}{l|} 
Dol: $10.1159 / 000373968$ \\
Published online: March 12, 2015
\end{tabular} & $\begin{array}{l}\text { O } 2015 \mathrm{~S} \text {. Karger AG, Basel } \\
\text { www.karger.com/cpb }\end{array}$ \\
\hline
\end{tabular}

hairpin RNA); PPT (Photofrin photodynamic treatment); MPT (mitochondrial permeability transition); ROS (reactive oxygen species); LPLI (low-power laser irradiation); JNK (c-Jun N-terminal kinase); ERK (extra-cellular-regulated kinase); UV (ultraviolet); Smac/DIABLO (second mitochondria-derived activator of caspase/diablo homolog); AIF (apoptosis inducing factor); LSM (laser confocal scanning microscopy).

\section{Acknowledgment}

This research is supported by Talents Research Start-up Funds of Yangtze University and the Program for Medical Talents of Hubei Province. We are grateful to Dr. Fengrui Tang for assistance in editing of the manuscript.

\section{References}

1 Srivastava M, Ahmad N, Gupta S, Mukhtar H: Involvement of Bcl-2 and Bax in Photodynamic Therapymediated Apoptosis. J Biol Chem 2001;276:15481-15488.

2 Triesscheijn M, Baas P, Schellens JH, Stewart FA: Photodynamic therapy in oncology. Oncologist 2006;11:1034-1044.

3 Usuda J, Chiu SM, Murphy ES, Lam M, Nieminen AL, Oleinick NL: Domain-dependent photodamage to Bcl2. A membrane anchorage region is needed to form the target of phthalocyanine photosensitization. J Biol Chem 2003;278:2021-2029.

4 Jakubowska M, Szczygieł M, Michalczyk-Wetula D, Susz A, Stochel G, Elas M, Fiedor L, Urbanska K: Zincpheophorbide a-highly efficient low-cost photosensitizer against human adenocarcinoma in cellular and animal models. Photodiagnosis Photodyn Ther 2013;10:266-277.

5 Jakubowska M, Sniegocka M, Podgórska E, Michalczyk-Wetula D, Urbanska K, Susz A, Fiedor L, Pyka J, Płonka PM: Pulmonary metastases of the A549-derived lung adenocarcinoma tumors growing in nude mice. A multiple case study. Acta Biochim Pol 2013;60:323-330.

6 Weishaupt KR, Gomer CJ, Dougherty TJ: Identification of singlet oxygen as the cytotoxic agent in photoinactivation of a murine tumor. Cancer Res 1976;36:2326-2329.

7 Seshadri M, Spernyak JA, Mazurchuk R, Camacho SH, Oseroff AR, Cheney RT, Bellnier DA: Tumor Vascular Response to Photodynamic Therapy and the Antivascular Agent 5,6-Dimethylxanthenone-4-Acetic Acid: Implications for Combination Therapy. Clin Cancer Res 2005;11:4241-4250.

8 Wu Y, Xing D, Chen WR: Single cell FRET imaging for determination of pathway of tumor cell apoptosis induced by photofrin-PDT. Cell Cycle 2006;5:729-734.

9 Zhou F, Xing D, Chen WR: Dynamics and mechanism of HSP70 translocation induced by photodynamic therapy treatment. Cancer Lett 2008;264:135-144.

10 Powell K: Bim plays apoptosis offense. J Cell Biol 2007;177:566-567.

11 Putcha GV, Le S, Frank S, Besirli CG, Clark K, Chu B, Alix S, Youle RJ, LaMarche A, Maroney AC, Johnson EM Jr: JNK-mediated Bim phosphorylation potentiates Bax-dependent apoptosis. Neuron 2003;38:899-914.

12 Lei K and Davis RJ: JNK phosphorylation of Bim-related members of the Bcl-2 family induces Baxdependent apoptosis. Proc Natl Acad Sci USA 2003;100:2432-2437.

13 Ley R, Ewings KE, Hadfield K, Cook SJ: Regulatory phosphorylation of Bim: sorting out the ERK from the JNK. Cell Death Differ 2005;12:1008-1014.

14 Chen MJ, Xing D: BimL involvement in Bax activation during UV irradiation-induced a pooptosis. Biochem Biophys Res Commun 2007;358:559-565.

15 Wang XW, Xing D, Liu L, Chen WR: BimL directly neutralizes Bcl-xL to promote Bax activation during UVinduced apoptosis. FEBS Let 2009;583:1873-1879.

16 Wang XW, Chen WR, Xing D: A pathway from JNK through decreased ERK and Akt activities for FOXO3a nuclear translocation in response to UV irradiation, J Cell Physiol 2012;227:1168-1178.

17 Claveria C, Martinez-A C, Torres M: A Bax/Bak-independent mitochondrial death pathway triggered by Drosophila Grim GH3 domain in mammalian cells. J Biol Chem 2004;279:1368-1375. 


\section{Cellular Physiology Cell Physiol Biochem 2015;35:1527-1536 \begin{tabular}{l|l|l}
\hline DOI: 10.1159/000373968 & C 2015 S. Karger AG, Basel
\end{tabular} www.karger.com/cpb \\ Wang et al.: Bim is Involved in Photodynamically Induced Apoptosis}

18 Kuroda J, Puthalakath H, Cragg MS, Kelly PN, Bouillet P, Huang DC, Kimura S, Ottmann OG, Druker BJ, Villunger A, Roberts AW, Strasser A: Bim and Bad mediate imatinib-induced killing of Bcr (Abl) leukemic cells, and resistance due to their loss is overcome by a BH3 mimetic. Proc Natl Acad Sci USA 2006;103:14907-14912.

19 Tsuruta F, Masuyama N and Gotoh Y: The PI3K-Akt pathway suppresses Bax translocation to mitochondria. J Biol Chem 2002;277:14040-14047.

20 Valentijn AJ, Metcalfe AD, Kott J, Streuli CH, Gilmore AP: Spatial and temporal changes in Bax subcellular localization during anoikis. J Cell Biol 2003;162:599-612.

21 Lu YY, Chen TS, Qu JL, Pan WL, Sun L, Wei XB: Dihydroartemisinin (DHA) induces caspase-3-dependent apoptosis in human lung adenocarcinoma ASTC-a-1 cells. J Biomed Sci DOI: 10.1186/1423-0127-16-16.

22 Angelastro JM, Moon NY, Liu DX, Yang AS, Greene LA, Franke TF: Characterization of a novel isoform of caspase-9 that inhibits apoptosis. J Biol Chem 2001;276:12190-12200.

23 Gilley J, Coffer PJ, Ham J: FOXO transcription factors directly activate bim gene expression and promote apoptosis in sympathetic neurons. J Cell Biol 2003;162:613-622.

24 Ewings KE, Hadfield-Moorhouse K, Wiggins CM, Wickenden JA, Balmanno K, Gilley R, Degenhardt K, White E, Cook SJ: ERK1/2-dependent phosphorylation of BimEL promotes its rapid dissociation from Mcl-1 and Bcl-xL. EMBO J 2007;26:2856-2867.

25 Hübner A, Barrett T, Flavell RA, Davis RJ: Multi-site phosphorylation regulates Bim stability and apoptotic activity. Mol Cell 2008;30:415-425.

26 Jakubowska M, Michalczyk-Wetula D, Pyka J, Susz A, Urbanska K, Płonka BK, Kuleta P, Łącki P, KrzykawskaSerda M, Fiedor L, Płonka PM: Nitrosylhemoglobin in photodynamically stressed human tumors growing in nude mice. Nitric Oxide 2013;35:79-88.

27 Hu SL, Du P, Hu R, Li F, Feng H: Imbalance of $\mathrm{Ca}^{2+}$ and $\mathrm{K}^{+}$fluxes in C6 glioma cells after PDT measured with scanning ion-selective electrode technique. Lasers Med Sci 2014;29:1261-1267.

28 Li Q Wang X, Zhang K, Li X, Liu Q, Wang P: DNA damage and cell cycle arrest induced by protoporphyrin IX in sarcoma 180 cells. Cell Physiol Biochem 2013;32:778-788.

29 Kano A, Taniwaki Y, Nakamura I, Shimada N, Moriyama K, Maruyama A: Tumor delivery of Photofrin ${ }^{\circledR}$ by PLL-g-PEG for photodynamic therapy. J Control Release 2013;167:315-321.

30 Wezgowiec J, Derylo MB, Teissie J, Orio J, Rols MP, Kulbacka J, Saczko J, Kotulska M: Electric field-assisted delivery of photofrin to human breast carcinoma cells. J Membr Biol 2013;246:725-735.

31 Li YJ, Zhou JH, Du XX, Jia de X, Wu CL, Huang P, Han Y, Sui H, Wei XL, Liu L, Yuan HH, Zhang TT, Zhang WJ, Xie R, Lang XH, Liu T, Jiang CL, Wang LY, Bai YX: Dihydroartemisinin accentuates the anti-tumor effects of photodynamic therapy via inactivation of NF- $\mathrm{kB}$ in Eca109 and Ec9706 esophageal cancer cells. Cell Physiol Biochem 2014;33:1527-1536.

32 Song J, Chen Q Xing D: Enhanced apoptotic effects by downregulating Mcl-1: evidence for the improvement of photodynamic therapy with Celecoxib. Exp Cell Res 2013;319:1491-1504.

33 Wagner A, Mayr C, Bach D, Illig R, Plaetzer K, Berr F, Pichler M, Neureiter D, Kiesslich T: MicroRNAs Associated with the Efficacy of Photodynamic Therapy in Biliary Tract Cancer Cell Lines. Int J Mol Sci 2014;15:20134-20157.

34 Hubbard BP, Gomes AP, Dai H, Li J, Case AW, Considine T, Riera TV, Lee JE, E SY, Lamming DW, Pentelute BL, Schuman ER, Stevens LA, Ling AJ, Armour SM, Michan S, Zhao H, Jiang Y, Sweitzer SM, Blum CA, Disch JS, Ng PY, Howitz KT, Rolo AP, Hamuro Y, Moss J, Perni RB, Ellis JL, Vlasuk GP, Sinclair DA: Evidence for a common mechanism of SIRT1 regulation by allosteric activators. Science 2013;339:1216-1219.

35 Jiang M, Wang J, Fu J, Du L, Jeong H, West T, Xiang L, Peng Q Hou Z, Cai H, Seredenina T, Arbez N, Zhu S, Sommers K, Qian J, Zhang J, Mori S, Yang XW, Tamashiro KL, Aja S, Moran TH, Luthi-Carter R, Martin B, Maudsley S, Mattson MP, Cichewicz RH, Ross CA, Holtzman DM, Krainc D, Duan W: Neuroprotective role of Sirt1 in mammalian models of Huntington's disease through activation of multiple Sirt1 targets. Nat Med 2011;18:153-158.

36 Xia L, Kong X, Liu X, Tu L, Zhang Y, Chang Y, Liu K, Shen D, Zhao H, Zhang H: An upconversion nanoparticle-Zinc phthalocyanine based nanophotosensitizer for photodynamic therapy. Biomaterials 2014;35:41464156. 